\title{
Imperial literacy and indigenous rights: Tracing transoceanic circuits of a modern discourse
}

\author{
Tracey Banivanua Mar
}

In 1838, amidst French imperial aggression in Tahiti, the reigning Indigenous monarch Queen Pomare wrote the first of many letters as a 'sister Queen' to Britain's Queen Victoria. In it she asserted her and her people's right to seek the protection of the British government who, after all, had brought colonisation to her shores. Two years later, Wurundjeri elder Billibellary, counselled a gathering of his clanspeople on a newly selected site of residence in Narre Narre Warren, a few miles remote from the burgeoning British settlement of Melbourne. Following his reportedly spirited address, he and other residents walked off the Narre Narre Warren station in a sovereign withdrawal of cooperation with colonial authorities. Earlier that same year, a few thousand miles to the east of Melbourne at Waitangi in Aotearoa New Zealand, a gathering of Maori chiefs walked out on treaty negotiations with a British delegation. Although some would eventually sign what became known as the Treaty of Waitangi, others permanently withdrew their consent and refused the British appropriation of full sovereignty over Maori land and its inseparable people. This article argues that these seemingly isolated moments of protest constitute the observable tip of a wider process underway within many indigenous communities in the late 1830s and 1840s.

The three moments of protest in 1840 did little in the long-term to stop the approaching waves of colonisation that radiated from Pacific rim colonies to engulf the entire oceanic region. By the end of the decade land and gold rushes in these rim colonies entrenched colonisation throughout the Pacific region as an expectation rather than potential. Settler-colonialism in particular, though an experimental and tentative idea in the 1830s, had solidified into a self-conscious and self-governing phenomenon in the Australasian colonies and many parts of the Pacific by mid-century. But success or failure in deflecting colonisation may not be where the potential significance of these protest moments lies. Viewing them with a wider-angled lens, this article suggests that their historical significance lies in indigenous leaders' adaptations of an imperial discourse that was dynamically articulating notions of 'protection', 'sovereignty' and 'land' in the early to mid-century. These imperial discourses can be viewed as the connective tissue that underpinned a developing consciousness amongst the original inhabitants of the region. Moreover, as this article explores, the extensive mobility of indigenous peoples and colonial traders, missionaries and 
settlers in the first half of the nineteenth century is an important framework for understanding what was arguably an emerging intellectual and discursive circuitry. In this wider context, isolated protest can arguably be re-viewed in terms of their shared patterns and contributions to emerging counter-imperial discourses on native rights.

The south-eastern Australian colonies, Aotearoa New Zealand, and Tahiti were interlinked colonial 'nodes' in the 1840s that connected an expanding and thickening British web of interests in land and labour throughout the Pacific. By the 1840s they were bustling sites of interdependent imperial proselytising, trade and settlement that imposed intensifying pressure on indigenous peoples. In turn indigenous peoples continued to adapt varied local forms of political management to meet the increasingly insatiable imperial hunger for land, labour, resources and territory. This interdependence is beginning to be more widely acknowledged in historical understandings of the region. ${ }^{1}$ Nevertheless, the potential for them to have been linked by intellectual, political and discursive threads in the same way that they were physically linked by imperial markets, bodies and trade has not been thoroughly explored. The roots of this neglect may well lie in the distinct circumstances and periods of colonisation across the three sites.

In some ways the colonisation of the Australian colony of Port Phillip, Tahiti and Aotearoa New Zealand could not be more different. Port Phillip was obtained by British settlers without serious legal recourse to prior indigenous title; New Zealand was annexed to Britain only after decades of informal colonialism and trade with whalers, sealers and independent settlers from New South Wales; and British-dominated Tahiti, with its close economic and missionary links with New South Wales and New Zealand, was obtained by France in an antiBritish act of imperial brinkmanship. Each acquisition was rooted in disparate expressions of ever-adaptable colonial legal apparatuses, and in accordance with matching constructions of the racially distinct abilities of Aboriginal, Polynesian and Maori peoples. ${ }^{2}$ With implications for the speed and brutality with which colonisation would proceed, these distinct circumstances impacted the capacity and form of indigenous political organisation across the three sites. Historical analyses of colonial experiences in each site has understandably emphasised differences. Moreover the national borders of the late twentieth century have tended to dominate historical perceptions of the nineteenth-century Pacific world more widely. ${ }^{3}$ While such attention to difference is warranted, so too is the neglected acknowledgment that the colonial world of the Pacific and its rim was not made up of mutually exclusive sites of colonial activity. Rather it was an interlinked, interdependent and highly contingent world of shared markets, trades and desires. In the case of Tahiti, Port Phillip and Aotearoa in the 1830s

1 For two recent examples and historiographies see Thomas 2012; Matsuda 2012.

2 For survey of the distinct legal foundations of colonial powers throughout the Pacific see Banner 2007.

3 For an early but transformative critique of the tendency to reduce Pacific history to its isolated micro-states see Hau'ofa 2008. 
and 1840s the colonial forces impacting indigenous peoples in each site were translocal. Each was partly shaped by the experiences of the other, as well as the new exploitation of indigenous Australians, Tahitians, Maori and other Pacific Islanders' trade, labour and resources mutually ensured the viability of colonial activity in each place. ${ }^{4}$

With the benefit of hindsight, colonialism in and around the Pacific was inevitable, if not settled, by the 1840s. Many indigenous peoples, however, still related to the imperial world at this time as sovereign peoples, albeit within widely varied constraints. As the three examples explored in this article indicate, archival records of indigenous protests, though sparse, remain indicative of a widespread expectation that colonisation could be contained, if not stopped, by the rights and sovereignty of native peoples. As the reference list for this article exemplify, much historical recognition of this activity has considered such protests in nationally-focused histories on either Australia, New Zealand or Tahiti. Historical indigenous protest therefore retains an aura of having been intensely local and constrained by the isolation and containment imposed during the height of colonial power.

Because of the frequently counter-imperial, suppressed or subversive nature of indigenous political activity, it is difficult to explore with certainty the extent to which it was informed, politically conscious or global. At the best of times, tracking transnational networks and circuits is an archive-intensive project that thrives on physical or hard networks through which the transmission of people, bodies and kin, ideas, discourse, and information can be tracked. The most relevant examples here are the imperial networks traced by Antoinette Burton, Alan Lester and Tony Ballantyne, which left archival traces in institutional records, newspapers or letters mapping the flow of settler, humanitarian, or racial ideas. ${ }^{5}$ But the empire's indigenous webs tend to flash in and out of the archival record. The links, connections and networks we seek to track were often subversive, frequently interrupted, and deliberately kept private from the imperial record. With such fleeting appearances, as Daniel Richter has demonstrated, sometimes only inference and the imagination, albeit consistent with available empirical evidence, can foreground indigenous peoples' historic thoughts, emotions, desires, anger and intentions. ${ }^{6}$

A growing number of studies based in the twentieth century, however, demonstrate useful models for working with limited archival collections. John Maynard, Ravi de Costa, and Fiona Paisley, for example, have explored transoceanic engagements between Indigenous Australians and the rest of the world in the twentieth century. ${ }^{7}$ Internationally too, Elleke Boehmer and Elizabeth Elbourne have paid increasing attention to conceptualising transcolonial indigenous networks that were by nature subversive, dangerous, resource-

4 Matsuda 2006; Matsuda 2012: 1-9, 216-255.

5 Lester and Dussart 2008: 205-220; Ballantyne 2002; Ballantyne and Burton 2005: 1-18; Ballantyne and Burton 2009.

6 Richter 2001: 12-14.

7 Maynard 2006; De Costa 2006; Paisley 2012 
limited, and fragmented over time. ${ }^{8}$ In these examples discourse, terminology, concepts and sentiment are an underlying, and not always emphasised, means of demonstrating the existence of counter-imperial and indigenous circuitry beyond mere physical or institutional contact.

The models offered by studies of more recent indigenous networks are useful references for exploring the translocal dimensions of indigenous protest in the early nineteenth century. During this time such disparate moments of protest as those in Tahiti, Port Phillip and Aotearoa were limited in the archival record to isolated flash points recorded for the purposes of colonial administration. Emphasis is therefore given in this article to exploring the shared expression and conceptual basis of each moment within their wider historical landscape. Juxtaposed against the wider context of a physically linked colonial world common if sometimes fleeting and ephemeral circuitry can be glimpsed. Unlike the hard and structural networks of empire that can be traced through the permanent, readable and constant infrastructure of global organisations or publications, however, such subaltern and indigenous circuitry invokes what Lester has described as transnational 'processes'. In a subtle analysis he has argued that imperial networking, particularly indigenous networking, should be seen as a process where connectivity might be visible only as shared or contingent trajectories rather than hard-wired networks. ${ }^{9}$ Such connectivity might be more subtly understood as connections in any given moment that are yet to be made, lost and made again; juxtapositions yet to flower; or moments of contact that are, by force of historical context provisional, contingent, or fleeting. In the following study it is therefore argued that the parallel imperial discourses - constituted by both language and actions - with which indigenous leaders engaged in these moments of protest in 1840 was not the product of mere coincidence. Viewed from the perspective of a physically connected colonial world, it is argued that these protests exemplify a new imperial literacy. It was a literacy that went beyond letters and numbers to a proficiency in concepts which, in turn, emerged from deeper counter-imperial processes.

\section{Queen Pomare: Imperial literacy and networks of 'protection'}

From the late eighteenth century, the island of Tahiti, and its port of Papeete, was deeply integrated in the tentative reach of British influence in the Pacific. The penal colony at Port Jackson, for example, heavily relied on the agricultural produce traded by Tahitians. So too a new brand of British evangelicals had established a Protestant base in and around Tahiti at the end of the eighteenth century and thoroughly entangled themselves in local politics and governance. By 1815 the Pomare family established a monarchy and stabilised traditional rule with a kingdom based in scriptural laws. Closely aligned with the British

8 Elbourne 2001; Boehmer 2002. A forthcoming collection of essays edited by Jane Lydon and Jane Carey will also showcase numerous new studies interested in 'extra-local' Indigenous networks and exchanges. See Lydon and Carey (forthcoming).

9 Lester 2006: 134-135. 
missions, when two French Catholic priests attempted to land in Tahiti in 1836, they were firmly ejected by the then reigning Queen Pomare. ${ }^{10}$ The French retaliated. They sent an armed vessel from Peru to Papeete in 1838 demanding that the Queen issue a formal apology to the King of France, hoist the French flag with a 21 gun salute, and pay a fine of 2,000 dollars. The inference of aggression was clear. If Pomare did not pay the fine, France would assert control and sovereignty over Tahiti.

Shocked by French aggression, Queen Pomare turned to the British government expressing confidence that 'my friend [Queen] Victoria ... will not cast me off in my troubles'. ${ }^{11}$ She overtly expected that British military protection against French aggression would be forthcoming, and wrote to Queen Victoria that it was the British who had opened the way to this new world of civilised aggression. '[S]ince the first Englishman neared our shores' she wrote, the British:

opened to us two new entrances to two new worlds ... with the assistance of Jesus Christ and the paternal care of the missionaries, we may hope to secure one of these worlds; [but] the other in which civilization leads us into, begins to embitter our life, and will ultimately deprive us even of the dominion of the graves of our ancestors. ${ }^{12}$

Between 1838, when Pomare first wrote to Queen Victoria, and the mid-1840s when she eventually relented to French claims of sovereignty over Tahiti, Pomare and her supporting chiefs wrote numerous petitions, manifestos and appeals to the British and French monarchs. Although she explicitly sought advice on British law and protocols from the British admiralty, consular staff and missionaries resident in Tahiti, the British Foreign Office was repeatedly assured that Pomare's letters, words, and expressions were her own and not dictated by others. As the British Consul insisted in 1844 her letters reflected her personal qualities of being 'quiet and dignified' with 'a strong mind [that] feels deeply what she says or writes'. ${ }^{13}$

In directly addressing European monarchs Pomare based her right to do so on her equal status as a 'sister' monarch, but also as a woman and a mother. ${ }^{14}$ In November 1843 when she addressed Queen Victoria simply as 'Victoria, the Sovereign of Britain' in reference to her normal expression of 'friend' or 'sister', she explained that 'I am no longer called a sister, because my lands have been

10 For more on the 1819 law code, based on the Ten Commandments see Gunson 1978: 284.

11 Queen Pomare to Captain Tucker, 3 October 1843, Enclosure 3, No. 150, The Honourable Sidney Herbert to Viscount Canning, 21 February 1844, The National Archives of the UK [TNA], FO 534/1 Foreign Office: Confidential Print Pacific Islands: Society Islands: Correspondence.

12 Queen Pomare and Chiefs of Tahiti to Her Majesty Queen Victoria, 8 November 1838, Enclosure 3, No. 67, Mr Consul Pritchard to Viscount Palmerston, 9 November 1838, TNA, FO 534/1 Foreign Office: Confidential Print Pacific Islands: Society Islands: Correspondence.

13 No. 275, Mr Consul-General Miller to the Earl of Aberdeen, 4 November 1844, TNA, FO 534/2 Foreign Office: Confidential Print Pacific Islands: Society Islands: Correspondence 'Private and Confidential'.

14 See for more on this: O’Brien 2006: 108. 
seized by the Admiral of France'.$^{15}$ Her dispossession, she said, had reduced her status from one of equality with the British Queen. So too in 1844 she addressed the King of France with a manifesto demanding he retract a treaty ceding Tahitian sovereignty to the French because it had been forced under threat of violence. In doing so, and as Pomare herself was 'near giving birth to another child' she appealed to his justice and good faith, and asked that he see her as both a monarch and a woman like his 'pious' Queen and mother of his children. ${ }^{16}$ In emphasising both her equality and gendered humanity, Pomare had not sought British 'protection' on the basis of Tahitian subordination or inferiority. She had done so instead on an assumption that 'protection' was what the British owed as friends and as a debt for ushering in that which, as she put it in 1838, had embittered Tahitian lives and threatened their domain. The British Foreign Office, however, approached her letters as an offer of cession to the British Crown, one which they rejected as 'dangerous and impolitic' ${ }^{17}$

Like the moments of protest in Port Phillip and Waitangi in the surrounding years, Pomare's campaign to resist colonisation was ultimately unsuccessful. But in protesting she left an archival trail that testifies to her conscious use of existing, and new transoceanic networks. Frequent consultations between Pomare and the Tongan monarch Tupou also revealed a keen understanding of French imperial aggression in the Pacific and a wider imperial 'design' to also 'take' Tonga, the Marquesas and Hawaii. In 1844 Tupou mirrored Pomare when he demanded British protection on the grounds that from the time Captain Cook anchored here we have viewed the English as our friends'. ${ }^{18}$ These lines of connection between the islands were thus both physical and discursive, as Tupou adopted a similar foundation for expecting British protection. While such circuitry reflected pre-colonial and indigenous lines of trade and genealogical reciprocity between Tahitian, Samoan, Fijian and Tongan islands, they were also grafted on to new imperial networks that were being carved through the Pacific by new trades and an inexorably expanding missionary empire. ${ }^{19}$ These were themselves reliant on existing indigenous circuits for their expansion, and would extend to connect indigenous worlds of the Pacific and Australia as never before.

In a condition that was somewhat unique to the Pacific experience of colonisation, British missionary and humanitarian networks were amongst the first, and certainly the most robust, imperial networks that structurally linked the Pacific world. The first missionaries, of the London Missionary Society (LMS), landed

15 Petition from Queen Pomare to Her Majesty Queen Victoria, 10 November 1843, No. 151, TNA, FO 534/1 Foreign Office: Confidential Print Pacific Islands: Society Islands: Correspondence.

16 Manifesto of Queen Pomare to King of the French, Enclosure 1, No. 270, Mr Consul-General Miller to the Earl of Aberdeen, 4 November 1844, TNA, FO 534/2 Foreign Office: Confidential Print Pacific Islands: Society Islands: Correspondence 'Private and Confidential'.

17 Mr Stephen to the Hon W Fox Strangeways, 1 August 1839, No. 70, TNA, FO 534/1 Foreign Office: Confidential Print Pacific Islands: Society Islands: Correspondence.

18 Tubou, King of the Friendly Islands to Her Majesty Queen Victoria, 19 February 1844, Enclosure 2, No. 253, TNA, FO 534/2 Foreign Office: Confidential Print Pacific Islands: Society Islands: Correspondence 'Private and Confidential'.

19 On pre-colonial trade, language and genealogical circuits throughout the Pacific see Denoon 1997: 96-105; Denoon et al 2000: 37-50. 
in the late eighteenth century in Tahiti, with various denominations across the Pacific, New Zealand, and to a lesser extent, Australia. Without state support, as missions would eventually enjoy in settler colonies, these missionary pursuits were intensely dependent on their indigenous hosts. Many arrived in the eastern and southern Pacific into a perfect storm of new colonial trades, new sources of wealth, and the devastation of indigenous populations caused by violence and regular or venereal disease. Population numbers as well as social, gender, economic and agricultural norms were destabilised or destroyed in the first decades of contact with Europe, leaving social fissures and gaps into which missionaries readily poured. In Tahiti, although LMS missionaries floundered on the brink of failure, personal friendships, a steep population decline and dramatics shifts in the political fortunes of the Tahitian elite turned their fortunes. King Pomare II converted in 1812 resulting in widespread conversion by decree of the Tahitian people. As was also the case in New Zealand and throughout Tonga, Samoa, Fiji and Hawai'i, indigenous leaders and elites found that missionaries were useful as diplomats and were frequently hosted by indigenous communities in return for their political and economic resources in the emerging colonial world.$^{20}$ In the Australian colonies and the western Pacific, however, indigenous people at first found limited use for missionaries until well into the nineteenth century. ${ }^{21}$

The Protestant missions and closely related humanitarian movement of the 1830s have been well studied. Amongst the most recent Alan Lester and Zoe Laidlaw have traced the extensive political and discursive networks that established formidable global organisations in the 1830s. Many of these networks were also indigenous. From at least the 1820s missionary societies began using what they called Native Teachers as 'a means unlimited' of forming the front line of an expanding Christian frontier. ${ }^{22}$ From the 1820 s, Islander missionaries went from Tahiti to the Society Islands, the Marquesas, the Cooks and Tonga; from the 1830s to Fiji and Samoa; from the 1840s to Melanesian islands in the New Hebrides and New Caledonia; and from the 1870s to the Australian colonies and New Guinea. In New Zealand, the Church Missionary Society schools established in many Maori villages were run by 'native youths', and by the 1850s, over 800 'native agents', mostly unpaid, worked for two Protestant missions throughout New Zealand. ${ }^{23}$ As the frontline of missionary expansion indigenous missionaries were vulnerable. Of around 250 new LMS missionaries sent to New Guinea from Tonga, Tahiti, Fiji, and Samoa between 1871 and 1885 for example, at least 130, along with what Norman Goodall has said was an 'unknown number' of wives

20 Simon 1998; Etherington 2005; Lang 2000.

21 For a most recent study Mitchell 2011: 1-12.

22 Howe 1984: 120.

23 Evidence of Reverend John Williams, Secretary of the London Missionary Society, 1837, 'Report from the Select Committee on Aborigines (British Settlements): with the minutes of evidence, appendix and index', Parliamentary Papers House of Commons, 425 [hereafter 'Report from the Select Committee on Aborigines '], p. 57; Lang 2000: 287. 
and children, died from disease and violence. ${ }^{24}$ This indigenous dimension of the missionary network transmitted and diffused spiritual, cultural and political knowledge in tandem with missionary teachings. ${ }^{25}$

Despite the diverse experiences and denominations throughout the Pacific and Australian colonies, missionary activity was linked by a common thread throughout the region. From Papeete to Waitangi, and Port Phillip to isolated parts of New South Wales, many indigenous peoples embraced the literacy and numeracy that accompanied the Bible as a means of engaging with the colonial world. ${ }^{26}$ In Tahiti, where a printing press was established in 1817 enabling the printing of Tahitian spelling books and religious pamphlets, Tahitians subsequently sought missionary education as much for its provision of literacy and numeracy, as for its religious content. ${ }^{27}$ Indeed by the 1840 s literacy appears to have been established as both the currency of imperial communication in Tahiti, as well as a desirable and entertaining culture. In a letter to the British ConsulGeneral in 1844, for example, the Chiefs of Papenoo on Tahiti requested that the Consul bring them no more letters from the French, for they did not like what they read. In addition, '[t]his is another little word:' they wrote, 'will you send us a little white paper, pen and ink, for we have no more paper to write letters upon', something they did as much for entertainment as for communication. ${ }^{28}$

Elsewhere in the Australian and Pacific colonies literacy and numeracy were also attractive. In New Zealand Maori actively and enthusiastically sought the expertise of missionaries and particularly the skills of literacy and numeracy. ${ }^{29}$ In Tonga too, the Wesleyan printing press produced at least 170,000 (religious) books in Tongan in the first year of operation, which were devoured by a literate Tongan audience. ${ }^{30}$ By 1837 the Secretary of the LMS, Reverend W Ellis stated that in the LMS' zone of Pacific influence there were '78 schools, which contain between 12,000 and 13,000 scholars'.$^{31}$ Even in the Australian colonies where missionaries enjoyed limited success, literacy quickly became a tool of both accommodation and protest for many post-frontier indigenous communities. ${ }^{32}$ By engaging the literacy of the missions in letters, petitions, and other engagements with British administration, indigenous peoples also entered into dialogue with the concepts and customs of imperial humanitarianism.

By 1840 many indigenous peoples throughout the Pacific world had accepted missionaries and their teachings to varying degrees and for varying purposes

24 Goodall 1954: 421.

25 See Gray 1990: 80-81; Etherington 2005: 7-8; Barker 2005: 86-106.

26 Curthoys and Mitchell 2012; van Toorn 2006; Etherington 2005: 276-281; McArthur 1978: $273-$ 282.

27 Howe 1984: 143-145.

28 The Chiefs of Papenoo to Mr. Consul-General Miller, 19 September 1844, Enclosure 1, No. 255, Mr Consul-General Miller to Mr Addington, 23 September 1844, TNA, FO 534/2 Foreign Office: Confidential Print Pacific Islands: Society Islands: Correspondence 'Private and Confidential'.

29 Simon 1998: 66-67.

30 Howe 1984: 188; Griffiths 2005: 154-155.

31 Evidence of Reverend W Ellis, 'Report from the Select Committee on Aborigines', p. 51.

32 Van Toorn 2006. 
ranging from spiritual to functional; as tools of literacy or vehicles for travel; and as allies and diplomats for political and economic empowerment. But as tools of empowerment, missionary networks and the un-amended discourses that sustained them, were ill-fitting. Indeed their brand of cultural transformation tended to be based in an intolerance that ensured colonialism was thoroughly and culturally insinuated into the lives of indigenous peoples. Epitomising this, in 1837 the LMS reported that all its native mission villages had replaced Islanders' 'little contemptible huts along the sea beach' with 'neat' settlements around the central buildings of a chapel, a school-house, a chief and missionary's house. The latter overlooked rows ' of white cottages a mile or two miles long, peeping at you ... under the splendid banana trees' ${ }^{\prime 33}$ This basic model of supporting religious proselytising with an insistent and relentless transformation of indigenous cultural, social and spatial practices into what was viewed as superior and in 'the European fashion', was endemic to dominant missionary activity. ${ }^{34}$

Regardless of denomination, the brand of missionary activity that was dominant in Australia, New Zealand and the Pacific was born of a particular social and economic context that equated Christianity with civilisation, and civilisation with European society. Indigenous peoples' entire social fabric was viewed as being in need of change, for as British humanitarians put it in 1837, 'true Civilisation and Christianity are inseparable ... No man can become a Christian' it was held 'without being a Civilised man'. ${ }^{35}$ With indigenous societies largely construed as the noble or ignoble antithesis of civilisation, missionary activity was notoriously intolerant of indigenous societies and therefore deeply assimilationist. Missionary Hugh Thomas wrote in 1818 for example that Islanders, in this case Fijians, were 'the very dregs of Mankind or Human Nature' and 'quite unfit to live but far more unfit to die'. ${ }^{36}$ To this extent, missionaries both loved and despised those they came to convert and were self-consciously both saviours and destroyers.

The duality of destroying in order to save recurred in British missionary discourse to encapsulate a tension that remained central to the brand of missionary-influenced humanitarianism that ascended to its peak political influence in Britain in the late 1830s. Humanitarian concerns about the treatment of native peoples in the British empire culminated between 1835-37 in the establishment of a British parliamentary Select Committee to inquire into the conditions of Aboriginal people throughout areas of British influence. The committee's procedures, findings and recommendations were dominated by a transnational network of humanitarians, missionaries, and supporters stationed on most continents and oceans under British influence and anchored by the political influence of Thomas Fowell Buxton. ${ }^{37}$ It collated evidence of violent appropriations of indigenous lands, the widespread use of forced labour, and sexual violence against indigenous women and children. The committee's

33 Reverend W Ellis, 'Report from the Select Committee on Aborigines', p. 56.

34 Reverend W Ellis, 'Report from the Select Committee on Aborigines', p. 50.

35 Coates, Beecham and Ellis 1837: 171, 174.

36 Gunson 1978: 197.

37 Laidlaw 2004. 
findings and recommendations had a deep impact in Britain, and in its aftermath the Aborigines Protection Society (APS) was formed out existing networks in $1837 . .^{38}$ The period provided an unprecedented opportunity for humanitarians and missionaries to find common expression throughout Australia, the Pacific, North America and southern Africa. It thus gave rise to an influential language of protection that revolved around ideas of the natural and inalienable rights of native peoples on the one hand. But its sting lay in its foundational presumption of the 'incapacity' of 'native inhabitants' to 'enforce the observance of their rights', and Britain's 'obligations' to interfere on behalf of inferior peoples on the other. ${ }^{39}$

The reports and evidence of the Select Committee on Aborigines demonstrated a genuine concern for the fate of native peoples amidst the creeping influence of notions of the fatal impact. ${ }^{40}$ It also demonstrated deep disdain for British settlers and traders, and a faith that British sovereign protection against settler greed was the key means of defending indigenous peoples. British sovereignty in this discourse was framed as superior and conducive to the spread of civilisation and Christianity. As such the form of 'protection' the Select Committee advised, was deeply interventionist. In the South Sea islands the Committee recommended more rather than less intervention in these 'Barbary States', with the appointment of consular agents, British judicial authority and where necessary the acquisition of sovereignty. In colonies already under British dominion such as the Australian colonies, however, the Committee recommended deep intervention in indigenous education and religious instruction overseen by 'protectors, whose duty it should be to defend them'. Ultimately intervention was framed as a repaid 'debt' to displaced and dispossessed native peoples. ${ }^{41}$

Protectionism of the early to mid nineteenth century was at once both anti and pro imperialism. But it embedded a lasting trope of the indivisible rights of native peoples, their ownership of land and their entitlement to compensatory education and religion. With its deeply imperial genealogy, however, it remained distinct from, and at odds with, indigenous peoples' own language or discourse. Coloured by the prevailing racial filters of nineteenth-century Europe, indigenous peoples figured in protectionist discourse as noble, untutored, and possibly doomed races who could neither be spared colonisation, nor left alone to navigate their own futures. As we can observe from Pomare's letters, however, this differed from the expressions of indigenous peoples themselves.

In gaining fluency in the imperial language of protection and humanitarianism, indigenous people such as Queen Pomare utilised its vocabulary to articulate

38 Heartfield 2011; Lester 2005: 65-73.

39 'Report from the Select Committee on Aborigines', p. 3. For a more detailed treatment of protectionism's multiple trajectories see Lester and Dussart 2008.

40 See the entire 'Report of the Select Committee on Aborigines'. Exemplary was Bishop Broughton's Australian evidence when he stated Indigenous people 'do not so much retire as decay; wherever Europeans meet with them they appear to wear out, and gradually to decay: they diminish in numbers; they appear actually to vanish from the face of the earth', pp. 10-11.

41 'Report of the Select Committee on Aborigines', pp. 83, 80. 
their own expressions of rights and entitlements arising from colonial encounters. In 1838 and beyond, she adopted this language to challenge French imperialism and call on British obligations. She jettisoned notions of native peoples, and particularly native women's, innate inferiority and vulnerability. For her there was no mysterious fatal impact behind her need for British protection, but a string of broken promises and military aggression. In calling for protection she and the chiefs who wrote in support of her demands developed their own discursive trajectories, invoking the rights, entitlement and protection that was so dear to humanitarian sentiment, but articulating them with indigenous meanings and expectations. In summoning the concept of 'protection', for example, Pomare also noted that Christianity and Civilisation were two worlds introduced uninvited to Tahiti by the British. While Tahitians hoped to harness the benefits of the former through missionaries, the latter remained untamed, troubling, and threatening, and something from which Tahitians now needed the British to shield them. Protection, in other words, was called for from a position of strength, a demand arising from a broken and uninvited promise and, as Pomare would later put it, the resulting 'cord with which we both are bound' ${ }^{42}$ It was not a duty owed to an inferior peoples. This refusal of colonial and racialised constructions of native inferiority was shared in the words and deeds of indigenous peoples beyond Tahiti's shores, and in ways that were intrinsically linked.

\section{Billibellary: Indigenous circuits and sovereign articulations}

When the district of Port Phillip and settlement of Melbourne was established on Wurundjeri country in the immediate aftermath of the Select Committee's report and recommendations, an experimental Aboriginal protectorate was imposed. Established in 1839, the protectorate was to be administered by four Assistant Protectors mostly recruited from humanitarian and missionary circles in Britain, and a Chief Protector of Aborigines, George Augustus Robinson. Robinson arrived in Port Phillip from Tasmania, then Van Diemen's Land. There he had negotiated the conditional surrender of Tasmanian combatants at the end of the Black War and subsequently managed Wybalena, the Aboriginal reserve on Flinders Island that had been established as a new home for the exiled Tasmanians. There, Wybalena residents not only recovered from the traumas of war, but by the late 1830s had begun a literary tradition of petitioning and letterwriting to protest the conditions of their confinement. ${ }^{43}$ When taking up his post at Port Phillip in 1839, Robinson took with him a group of Wybalena residents, men and women who were well-travelled, war-weary and experienced in the colonial world, and who Robinson hoped to employ as intermediaries and translators. Robinson and the group travelled separately, with Robinson arriving in Melbourne to find the 'Van Diemens Land Natives' already mixing readily with Wurundjeri. A big group had 'congregated in [Melbourne] in considerable

42 Petition from Queen Pomare to Her Majesty Queen Victoria, 10 November 1843, No. 151, TNA, FO 534/1 Foreign Office: Confidential Print Pacific Islands: Society Islands: Correspondence.

43 Ryan 2012: 217-272; Attwood and Markus 1999: 30-31, 37. 
numbers' and Robinson was delighted that their engagement was 'of the most friendly character' and that 'the Van Diemens Land Natives are ... in friendly alliances with the Tribes' of Port Phillip.

Although initially delighted with the ready alliances that developed between Tasmanians and the Wurundjeri, Robinson would eventually fail to control the contact, and consequently came to resent it. ${ }^{44}$ Wybalena residents in Port Phillip continually resisted his attempts to limit their movement. Although Robinson hired out their services to local settlers many, like Peter Bruny, repeatedly absconded to gain independent work or reside with local Koori communities. ${ }^{45}$ Robinson eventually deported them from Port Phillip in 1842, but his anxieties during their stay epitomised the importance the colonial administration had begun to place on the regulation of indigenous space, bodies and territory. ${ }^{46}$ Moreover the contact was emblematic of the kind of concentric circuits that would link the Wurundjeri's experiences of colonialism, and in turn Billibellary's 1840 protest, to a wider imperial world.

The Wurundjeri, and specifically the Woiwurrung clan led by Billibellary, on whose land the settlement of Melbourne had been established, were administered by the Assistant Protector William Thomas. Thomas was a schoolteacher who arrived into his role more or less straight from London and in the first few years after his arrival in Port Phillip, lived and moved with Wurundjeri people, Billibellary among them. He also focused intently on searching for available land that could be reserved for Indigenous settlement, and on which the Wurundjeri and other Kooris could reside. Promoted by the protectorate as a means of isolating Kooris from settler society, the reservation of land was also justified as establishing a contained sedentary population amongst whom the presumed benefits of civilisation and Christianity could be disseminated as it had on the Pacific missions. Thomas' reports to Robinson show emphatically, that while the suitability of reserved land was to be based on the government requirement of being isolated from and unwanted by settlement, Wurundjeri persistently reframed the requirement to Thomas' increasing frustration. False starts on land at Arthurs Seat and the surrounds of Melbourne indicated to Thomas and the protectorate that if the land was not significant to, nor culturally appropriate for the Wurundjeri, they could not be compelled to either reside or stay. ${ }^{47}$ It was a quiet insistence on the internal autonomy or sovereignty of Wurundjeri over their own mobility, residence and emplacement.

44 Robinson to Superintendent of Port Phillip, relative to V.D.L. natives, 12 December 1839, Public Record Office Victoria [PROV], VPRS 10 1839/325.

45 PROV, VPRS 10 1839/325; Contract of labour for Peter Bruny contained in Robinson to Superintendant of Port Phillip, relative to V.D.L. Natives, 18 December 1839, VPRS 10 1839/334; Hill \& Coates to Chief Protector of Aborigines concerning a hired V.D.L. native who absconded, VPRS 10 1841/88.

46 This is explored at length in a comparative analysis of Melbourne in Vancouver in Edmonds 2010.

47 Standfield 2011; Broome 2010: 81-83. 
In 1840 Thomas reported triumphantly to Robinson that the Wurundjeri had chosen a block of land in Narre Narre Warren, an area remote from the Melbourne settlement. He described it favourably as hilly, rangy and unattractive enough that it 'never can be desired by the squatter or purchaser' and where 'the natives will have an undisturbed possession for hunting' ${ }^{48}$ Approved of by the Wurundjeri, a small group moved away from Melbourne and on to the block with Thomas. But once established, relations began to sour. Although rations and supplies had been promised by government as part of the establishment of Aboriginal stations and to ensure dependency, it never materialised. Thomas therefore struggled, as he had elsewhere, to keep people on the station and to prevent them from leaving at will to return to Melbourne for much needed work and supplies.

By December 1840 encroaching settler interest in the fertile lands surrounding Narre Narre Warren meant that the station's boundaries were increasingly construed by Thomas as containment lines that kept Wurundjeri in, rather than settlers out. Resisting the changed emphasis, and in protest against the lack of rations and broken promises, Narre Narre Warren residents met early in December in Thomas' absence. Following lengthy debate that reached late into the night, Billibellary, both a traditional clan leader or ngurungaeta and a chief negotiator with colonial officials, addressed the group with an argument that 'was long and no doubt weighty'. Although not there and unable to converse in Indigenous languages anyway, Thomas later reported that 'evil alarming ideas ... was put into their minds' by Billibellary and he felt that many 'expected had they remained that they would all have been killed' by settlers. ${ }^{49}$ Whether Thomas' suppositions were correct or not, they nevertheless convey the accumulating depth of feeling, uncertainty and resentment that resided amongst the Wurundjeri after months of repeated and often violent displacement and broken promises. ${ }^{50}$ Thomas' letters to Robinson, in which he relays both the dialogue and sentiments of Billibellary and others, reported a growing expressive discontent with the repeated relocation of Kooris from Melbourne, and the related failure of promised rations in the lead up to this December evening. ${ }^{51}$ The day after Billibellary's speech many residents were moved to walk off the station, but camped close enough that remaining residents, and Thomas, could still see the smoke from their fires. To Thomas this underscored the Wurundjeri's insistent autonomy of movement by retaining communication with the residents who remained and partially dissolving the imposed borders of the station. ${ }^{52}$

48 William Thomas Assistant Protector Westernport District, Narre Narre Warren to G A Robinson, Chief Protector of Aborigines, 26 September 1840, PROV, VPRS 11 Item 330.

49 William Thomas Assistant Protector Westernport District, Narre Narre Warren to G A Robinson, Chief Protector of Aborigines, 28 December 1840, PROV, VPRS 11 Item 335.

50 Standfield 2012; 2011: 162-185; Edmonds 2009.

51 Many of these letters are contained in PROV, Series VPRS11 Unregistered Inward Correspondence to the Chief Protector of Aborigines. Particularly Items 297, 299, 312, 324, 326, 327, 331, 335, and 363. See also Standfield 2011; Byrt 2004.

52 William Thomas Assistant Protector Westernport District, Narre Narre Warren to G A Robinson, Chief Protector of Aborigines, 28 December 1840, PROV, VPRS 11 Item 335. 
All residents eventually returned to Narre Narre Warren, but the station was eventually abandoned in favour of a block of land preferred by Wurundjeri at Coranderrk. ${ }^{53}$ To judge it as a failed strategy however, would ignore its context. The walk-off's deeper significance potentially lies in its role in a longer campaign waged by Wurundjeri peoples during the 1830s, 1840s and beyond, that sought to assert and maintain their increasingly curtailed rights to manage movement through country. ${ }^{54}$ As elsewhere in the Port Phillip district Kooris made good use of the protectorate system and humanitarian networks not just to seek refuge from raging frontier violence, but also to articulate longer-term demands and requests. These overwhelmingly centred on land as a source of sustenance and a precondition for cultural and social privacy, autonomy, and political renewal. Frequent disputes and disagreements between Thomas and Billibellary for example, were not just the result of clashing perceptions regarding who served who. ${ }^{55}$ At the heart of repeated refusals to stay in or vacate spaces epitomised by the Narre Narre Warren walk-off, was an insistence that land and space was not just about location and agriculture. Rather, the land had to legitimately belong to its residents, with legitimacy stemming from Indigenous not British legal foundations. As the Wurundjeri repeatedly requested, they wanted 'land in our own country'. ${ }^{56}$ So too, the residing resentment of Billibellary and his supporters caused by the repeated failure of promised rations, suggests these too were approached by Wurundjeri as necessary, even compensatory entitlements, rather than gifts and handouts.

The sentiments of Billibellary and the Wurundjeri were not unique in and around Port Phillip. The Wauthawurrung near Geelong also requested missionary Francis Tuckfield help them secure land of their own so they could be self-sufficient. ${ }^{57}$ Indeed throughout the eastern Australian colonies from the 1840s, Aboriginal people either directly requested grants of land, recruited white supporters to convey their desire for land, or directly reoccupied and squatted on land in their country. ${ }^{58}$ Forming what Heather Goodall has described as an early land rights movement, such demands for land as both asylum and compensation matured later in the nineteenth century into vibrant cultures of protest and what Richard Broome has called a 'powerful narrative of entitlement' in indigenous peoples' and their supporters' political engagement with colonial governments. ${ }^{59}$ Indeed Indigenous people throughout Victoria, New South Wales, South Australia and Queensland during the nineteenth century sought various methods of obtaining land for their own social and economic purposes. Later in the nineteenth century colonial governments would increasingly legislate around such spaces so that they operated more like open-air prisons, or 'carceral archipelagos' where residence was increasingly prescribed by law. ${ }^{60}$ But Aboriginal people

53 Broome 2005: 34.

54 Broome, 2005: 1-182; van Toorn 2006: 123-151; Barwick 1998.

55 Standfield 2012.

56 Curthoys and Mitchell 2012: 188; Barwick and Barwick 1984: 9.

57 Curthoys and Mitchell 2012: 188.

58 Goodall 1990: 1.

59 Curthoys and Mitchell 2012: 190.

60 Blake 1998: 58. 
nevertheless continued to frame claims, requests and demands for land, even reserve land, as sites of sovereignty, compensation or asylum. Moreover, as Queensland land claimants put it as late as 1876, they frequently only requested land that 'we and our ancestors from time immemorial have possessed and used'. ${ }^{61}$

That Indigenous peoples in the Australian colonies utilised available colonial structures and political avenues to pursue colonial concessions is neither surprising nor remarkable. Numerous scholars, such as Penny van Toorn, Ann Curthoys, Jessie Mitchell and others cited in this article have explored the very active indigenous political and literary history during this period. Yet to be examined however, is whether such activity merely coincided with, or was connected to and informed by similar activity elsewhere. At the very least, we know that the politics of insistence evident in demands for land, and the walk-off protest at Narre Narre Warren occurred in a broader context in which Indigenous people throughout the southern Australian colonies knowingly met the challenges of colonisation. By 1840, for example, Billibellary had already been part of a Kulin nation delegation that met speculator John Batman in 1835. These meetings, Batman later falsely claimed, secured a treaty to the land on which the protectorate of Port Phillip would later be established. ${ }^{62}$ Far from a chance meeting, recent historical scholarship has suggested that these meetings were the product of an informed response by Koori people to unfolding conditions to the north in New South Wales, and the south in Van Diemen's Land. ${ }^{63}$ Robert Kenny has argued that trade routes and overland relationships ensured that news from the north travelled to what would be the Port Phillip district. ${ }^{64}$ To the south too, sealing communities along the coast worked by Tasmanians, Maori, Tahitians and other Pacific Islanders potentially ensured news of colonial exploits travelled ahead of settlers. In what Rachel Standfield has described as the first recorded protest against the stinginess of colonial freedoms and rations, Billibellary openly compared the administration of the Port Phillip district to the potential promised by Batman. In 1839 when Wurundjeri were being forcibly cleared from the outskirts of Melbourne, he demanded of William Thomas: 'Why you want Black Fellows away? Plenty long time ago Maregeek [good]. Batman come here. Black Fellows stop long long time. All Black Fellows plenty bread, plenty sugar' ${ }^{65}$ Viewed in the longer and wider duration of consistent political protest, the Narre Narre Warren walk-off takes on a deeper significance as an integral part of a longer engagement with the colonial world that was actively informed by the translocal experiences of indigenous peoples elsewhere.

61 Petition by James Diper, Charles Diper Ghepara and William Watiman Nilapi, 'Being aborigines of Queensland'. Cited in 'The Revd. Duncan McNab and the Aborigines', Queensland Votes and Proceedings, (1876), p. 172. See also Banivanua Mar 2007: 82-84.

62 Attwood 2009.

63 Broome 2005: 10-14. See also Attwood 2009.

64 Kenny 2008.

65 This was in response to the expulsion from Melbourne of over 300 Wurundjeri and other Kooris. Thomas to Robinson, 1 January 1840. Cited in Fels 2011: 21. 
If Wurundjeri people such as Billibellary were informed by events in other Australian colonies, we should also reflect on the potential connections from further afield. As Lynette Russell has most recently explored in relation to Australia and as others have explored in relation to the rest of the Pacific, maritime industries, missionary pursuits or curiosity led to extensive mobility amongst many indigenous peoples in and throughout the Pacific in the early uncertain decades of the nineteenth century. ${ }^{66}$ Some such as the Tasmanian sealer Wore-temoe-teryenner, who had been born amongst the Trawlwoolway of Van Diemen's Land in the 1790s, worked in the Bass Strait in the first decades of the nineteenth century. There she lived with new sealing societies of the Bass Strait and Kangaroo Island that were made up of Maori, Pacific Islander, African American and European men, and Aboriginal and presumably Islander women from Tasmania and the south coast of the Australian mainland. In the 1820s she and three other Aboriginal women worked as far afield as Mauritius where they were stranded for years, but eventually returned to Tasmania via Sydney in 1827. ${ }^{67}$ Wore-temoe-teryenner's story distils a wider history. Many Maori, Tahitians and Hawai'ians travelled independently throughout the Pacific, and to New South Wales, Britain, Asia, the United States and South America. Many thousands of others travelled as labourers on the whaling, sealing and trading vessels that criss-crossed the Pacific and Southern Oceans in the early nineteenth century, weaving together ports in New South Wales, Van Diemen's Land, and the entire southern and south-western Australian coast to bustling ports in New Zealand, Tahiti, Hawai'i and the North and South American coastlines. ${ }^{68}$ The maritime industries of the southern seas therefore linked the Pacific, Atlantic and Indian Oceans with crews collected from throughout their travels, including African Americans, Indian and south-east Asian indentured labourers, and Aboriginal, Maori and Pacific Islander crews.

We should not, of course, assume that just because maritime workers travelled together they necessarily conversed about anything more meaningful than the weather, diet or everyday functions of maritime labour. But we do know it was linguistically possible to have deeper exchanges. The Pacific's trade and pidgin languages, for example, grew in currents that flowed from the Caribbean and Atlantic via encounters between English speakers and Indigenous Australians on the coast of New South Wales. ${ }^{69}$ Functional words like 'by-and-by', 'savvy', and 'plenty' for much, were common to Caribbean creoles, Pacific Pidgins, Australian Aboriginal English and Torres Strait Islander Broken and were peppered with African inflections. So too, more subtle or emotional terms like 'picanniny' for child, 'bra' or 'brother' for male peer, or 'shame' show direct linguistic links between Jamaica, the Bahamas, Hawai'i, New South Wales and

66 Russell 2012; Samson 2010; Pybus 2006; Thomas 2012.

67 Walter and Daniels 2008: 35-44; Russell 2012: 1-22, 93-116, 117-135; Plomley and Henley 1990: 33.

68 Chappell 1971.

69 Tryon and Charpentier 2004: 1-4, 65-114. 
the Torres Strait. ${ }^{70}$ These shared languages, scholars have argued, indicate a global linguistic circuitry and, of relevance to this study, a vehicle for transmission that was as structurally significant as missionary networks.

Indigenous peoples' movements left criss-crossing tracks across and between the colonial worlds of the southern oceans, physically linking indigenous peoples and interests throughout the Pacific, Aotearoa, and Australia's northern and southern beaches. This is not evidence of an ideological or conceptual connectivity in and of itself. Rather, and more subtly, it constitutes the historical medium through which spatially isolated political moments of indigenous protest that may have shared a language or sentiment, can be viewed as more than mere coincidence. In 1840 when Billibellary staged, what for Thomas and the Port Phillip administration was a misguided and minor protest, he also engaged in a longer, more spatially diverse campaign. Just as Pomare had done in Tahiti, Billibellary's singular and cumulative actions injected indigenous perspectives into a growing global movement. His actions engaged a wider emergent discourse on humanitarianism that, having been introduced to indigenous communities by missionaries and others, was being acclimatised to local sites of colonisation. He, like Pomare refused a colonial status of inferiority and insisted upon his and the Wurundjeri's innate sovereignty and rights. As was the case elsewhere sovereignty, access to land, and rights to mobility were emerging as central and on-going demands.

For the Wurundjeri in 1840, the Narre Narre Warren walk-off was not isolated, but was connected by concentric circuits ridden by trade, missionary and indigenous traffic to other Koori nations, to Indigenous Tasmanians, and to Maori, Pacific Islanders and beyond. In the absence of the kind of archival treasure left by the hard-wired networks of transnational organisations or institutions, such subaltern indigenous circuits need to be understood in Lester's terms as 'processes'. In the case of the Pacific and Australian worlds of the early nineteenth century, such processes were constituted by the overlapping colonial worlds of maritime trade, and fleeting moments of physical contact. For these carried the potential for parallel and shared political discourses to entwine.

\section{The Maori Confederacy: Managing imperialism}

In early February 1840, a series of talks between a large gathering of Maori and British spectators debated the terms of a potential treaty that would cede Aotearoa to Great Britain. Maori and mostly British settlers and missionaries had engaged with each other as traders of goods, labour and land for much of the nineteenth century. After decades of informal colonisation and intense destabilisation and conflict in Maori communities, by the late 1830s Europe was beginning to view the north island of New Zealand as prime colonial land and territory. The pressure on Maori landowners built in the 1830s, and in 1837 the Wakefield-led New Zealand Company was established with an urgency

70 Holm 1992: 187, 185-186, 194; Clark 1979. 
driven by circulating rumours of intensifying French colonial intent. Two years earlier, in 1835, a group of Maori chiefs of the North Island declared themselves an independent confederacy, emulating similar activity that had taken place in Tahiti and Hawai'i ${ }^{71}$ But by 1840 the British and other European nations rejected their demands for recognition and were yet to properly acknowledge their sovereign claims. At the gathering in February 1840, heated 'arguments and endeavours' occurred as the British attempted to induce the same Maori chiefs to sign a treaty ceding sovereignty and pre-emptive rights to purchase land to the British Crown. The 'meeting broke up' eventually, with 'every chief refusing to sign'.$^{72}$ The majority continued to refuse cooperation with the totality of annexation that Britain proposed, but after intense lobbying a much smaller group of around 40 chiefs eventually signed what became known as the Treaty of Waitangi. ${ }^{73}$

Shrouded in the humanitarian vocabulary of protection the English version of the Waitangi treaty ceded Maori sovereignty, or kawanatanga (governorship) in Maori. In Article 2 of the English treaty Maori were promised 'the full exclusive and undisturbed possession of their Lands and Estates Forests Fisheries and other properties'. Finally in Article 3 the English treaty promised to Maori the Queen's 'royal protection' and the provision of 'all the Rights and Privileges of British Subjects'. The Maori version of the Treaty of Waitangi, however, was translated in a hurry by missionary Henry Williams who was competently literate in the language, and who used Maori equivalents for terms such as land, property, and sovereignty that had far broader meanings. ${ }^{74}$ Still the most controversial section of the treaty, Article 2 in Maori promised 'te tino rangatiratanga' over 'wenua', or as many have since argued, it promised chiefly dominion over resources and land. Throughout the Pacific, and in Maori, however whenua tended to mean not just land, but the people of the land, or the people the land sustained. In other words it contradicted Article 1, maintaining dominion and sovereignty over both the land and people, and cast doubt on exactly what sovereign power had been ceded by Maori signatories. Indeed in the days that followed the United States observer Charles Wilkes wrote after an interview with one of the signing chiefs, that he and many others thought 'they have not alienated any of their rights' and were 'not under the impression [they] had given up ... authority, or any portion of $\ldots$ land permanently'. ${ }^{75}$

The relationship of land to people, people to chiefly dominion or sovereignty, and therefore sovereignty to land was poorly captured either in English, or by the constitutional and protectionist language of the Treaty of Waitangi. Many have since argued that only the governorship of British subjects within the colony, not the sovereignty of Aotearoa, its lands and its people, was granted

71 Facsimiles of the Declaration of Independence and Treaty of Waitangi.

72 Wilkes 1845: 375.

73 Orange 2011: 16-63; Belich 1996: 181-187.

74 For a recent study of the translation practices of missionaries in New Zealand see Samson 2010: 96-98. On the standardisation of the northern New Zealand language as 'Maori' in the late 1830s, see Sanderson 1983: 166-184; Landau 2005: 195-199. 
to the Crown by Maori signatories. ${ }^{76}$ While the ambiguity regarding the relative rights of possession enshrined in the treaty would continue to provide a legal foundation for both Maori and Pakeha claims in New Zealand into the twentyfirst century, it is significant here for another reason. In the context of its time in 1840 , it points to the patterns of campaigns by indigenous peoples in the 1840s to secure or manage their colonial futures in the face of destabilising waves of colonisation.

The activities of Queen Pomare, Billibellary and Maori chiefs epitomise a wider historical trend. Indigenous peoples were dynamic in their adoption of the only imperial languages and traditions that colonial subjects could or would contemplate, and they were creative in the methods they trialled. This is not surprising. By the 1840s and throughout the Pacific region, including Australia and New Zealand, whether imposed or invited, indigenous peoples had made good use of the skills - especially of literacy - that accompanied missionary education and colonial employment. But as the Treaty of Waitangi showed, like Queen Pomare's letters before it, the vocabulary and concepts available through such education were not a perfect fit. Nevertheless, in indigenous strategies that emerged in the early period of the nineteenth century - such as attempts to articulate land rights; construct kingdoms; establish embryo hybrid legal systems; or petition extra-colonial powers - the appropriation of imperial languages to express indigenous concepts demonstrated a deeply adaptive quality. Political traditions were consolidated that, like petitioning and letter-writing, attempted to reach beyond local colonial circumstances to an external, higher, or universal authority such as the Crown, God, or Law to adjudicate the partisan bias of colonial concerns. That is, they were translocal in their appeal, and tested what we might now recognise as notions of internal and group-specific rights that transcended local authority.

By the end of the 1840s the high-minded humanitarian impulse to ameliorate the destructive impact of colonial contact, trade and settlement seemed to have run its course. For indigenous observers across the Pacific, the British colonial world was therefore entrenched by the 1850s. News of events in the southern reaches of the Pacific Ocean and the rapid, violent and total occupation of the settler colonies in Australia and New Zealand travelled along the trading and missionary lines of contact demonstrating that the colonial world had arrived to stay and was hungry for land and permanent political control. In Australia the Port Phillip experiment was considered a failure. Robinson and the protectorate staff despaired at stemming the destructive and frequently vindictive violence against the Koori population that ravaged the western and south-eastern districts of the colony. ${ }^{77}$ As had been the case in New South Wales and Tasmania,

76 Literature on the treaty and key terms relating to land and sovereignty is vast. See for good overviews Orange 2011: 11-15, 230-267; the contributions to Kawharu 1989; Moon 2002.

77 On frontier violence in Victoria see Clark 1995; Edmonds 2009. 
many Indigenous peoples were dispossessed of sweeping swaths of territory in less than a generation depriving them of access to critical sources of physical, economic and cultural sustenance. ${ }^{78}$

In New Zealand the initially high-minded emphasis on protecting exclusive and absolute Maori possession of land rapidly gave way to a Crown emphasis on its own right of pre-emption and the need for Maori 'amalgamation' into Pakeha society. ${ }^{79}$ The treaty was widely seen as simply providing security of tenure and a legal foundation for settler purchases of land - both legal and illegal. The resulting full-scale settlement of New Zealand's North and South islands gave rise to widespread displacement and dispossession of Maori landowners and by 1844 some northern parts of the colony were at war with Maori in sporadic and violent conflict that would escalate into the New Zealand Wars and last until the 1870s. By at least 1847 the New Zealand colony was under pressure from the newly established Colonial Office in London to occupy and acquire what was, in the post-humanitarian paradigm, viewed as 'waste' Maori land. ${ }^{80}$ By the 1850s the provisions of the treaty were largely considered a quaint anachronism by settlers. A decade later two-thirds of the South island and a quarter of the North island had been alienated in patterns of dispossession that continued until 1975..$^{81}$ The protectionist experiment had clearly evaporated.

A willingness by some Maori to treaty with Britain in 1840 was one amongst diverse attempts by indigenous peoples in Australia and the Pacific to manage the imperial or colonial wave which, as we have seen, was detected long before its full impact hit. Although frequently considered in New Zealand as a starting point for the colonial state, and legally constructed as the Maori 'Magna Carta' providing the foundation for the nation, this captures only one side of the history of the treaty. ${ }^{82}$ From another perspective it was inseparable from a longer Maori campaign to manage British interest in New Zealand as a unified force, and which became visible with the declaration of independence in 1835. The Maori demand that European nations see them as sovereign and independent paralleled what Pomare had done in Tahiti in previous years, and what Billibellary would do in Port Phillip on a smaller scale. It was a grand gesture using an imperial language, but only a single tactic in a longer, translocal campaign of bracing for colonisation, and articulating indigenous rights and entitlements against a demonstrated colonial capacity for brutal disregard of indigenous peoples. While, in the case of the Treaty of Waitangi, the process or device was derivative of missionary tactics throughout the humanitarian period, it had its own characteristics. Maori signatories did not appear to separate land and sovereignty, and the form of protection that signatories agreed upon in the final treaty and years following, was viewed as it had been in Tahiti, as protection

78 Weaver 2003.

79 Orange 2011: 151-173; Ward 1974.

80 In 1847, the Secretary of State for the Colonies, Earl Grey, ordered the incoming New Zealand Governor to consider all Maori land not possessed under Lockean notions of property, to be 'waste' and available for settlement. See Williams 1999: 108-114; Charters and Erueti 2008: 34-35.

81 Denoon et al 2000: 130.

82 McHugh 1991. 
from other colonial interests, not (as the British saw it) as protection from their own 'native' ways. Although the treaty was signed, their refusals beforehand, lost now to a history that focuses on the signed treaty, reminds us that it was produced by crossed purposes attempting to achieve arguably radically different outcomes. As such the heated negotiations over the terms of a treaty that Maori viewed as having the potential to protect their interests, paralleled letter-writing and petitioning activities in Tahiti, or the spatial protests of Wurundjeri in Port Phillip.

\section{Conclusion: Imperial eloquence}

For indigenous peoples the 1840s was an exceptionally vocal and articulate period in the resistance to and accommodation of empire in the Pacific antipodes. As the moments of protest explored here suggest, in many parts of the region indigenous peoples still saw colonists as intruders or guests on their country, and as visitors and equals without the entitlement to rule that settlers saw in themselves. Indigenous peoples also had not yet been thoroughly required by introduced laws, as would be the case in the later nineteenth and twentieth centuries, to see colony and empire as superior rulers and themselves as inferior victims. The humanitarian experiment, at its height of influence in the late 1830s, was planting discursive seeds on which indigenous leaders freely grafted their own translated meanings. Influential imperial discourses of protection, sovereignty, and rights in land emerged in consultation with local missionaries, and enjoyed something of a symbiotic development. These discourses were not set in stone, but were adaptive, receptive and articulated in a common language that indigenous political leaders like Queen Pomare, Billibellary and the Maori elite further refined. The role of missionaries and humanitarian discourses was therefore important. But as the political moments of the 1840s indicate, this importance was less as a source of influence, and more as a vehicle. For indigenous groups utililised missionary and humanitarian circuits, adopting and adapting imperial discourses to articulate the new threat that the colonial era posed, and the foundations on which indigenous people wanted it to proceed.

This article has argued that although more sparse and difficult to access in the nineteenth century, some indigenous peoples in Australia and the Pacific exploited available opportunities to gain a proficient 'imperial literacy'. In the process they accessed and adapted the underlying circuitry, both physical and discursive, and used it in attempts to transcend local colonial authority. What emerged were shared, translocal and informed political processes that translated and communicated indigenous peoples' expectations to imperial audiences in a recognisable language. Pomare, Billibellary, and the dissenting Maori chiefs shared a common conceptual apparatus, common ways of articulating and expressing concepts of rights, and they inflected the expression of these with deeply localised and indigenous concerns. But most of all, they shared a knowledge of the colonial storm brewing in the late 1830s and 1840s, a knowledge gleaned from their own physical and epistemological travels. 
Over the remaining nineteenth century, these counter-imperial circuits would chase imperial networks as they globally linked colonial outposts, retaining the potential to bloom into modern and truly transoceanic discourses of indigenous rights.

\section{References}

\section{Archival sources}

The National Archives of the United Kingdom, Kew

FO 534/1 Foreign Office: Confidential Print Pacific Islands: Society Islands: Correspondence.

FO 534/2 Foreign Office: Confidential Print Pacific Islands: Society Islands: Correspondence 'Private and Confidential'.

Public Records Office Victoria, Melbourne

VPRS 10 Inward Registered Correspondence to the Superintendent of Port Phillip District, relating to Aboriginal Affairs, 1839/325 Robinson: relative to V.D.L. natives and other.

VPRS 10 1839/334 Robinson: relative to V.D.L. Natives, clothing \& victualling for the same. N.B. includes contracts of service for V.D.L. natives Newton to Robinson - quoting cost of rations etc.

VPRS 10 1841/88 Inward Registered Correspondence to the Superintendent of Port Phillip District, relating to Aboriginal Affairs.

VPRS 11 Unregistered Inward Correspondence to the Chief Protector of Aborigines.

\section{Government Publications}

'Report from the Select Committee on Aborigines (British Settlements): With the Minutes of Evidence, Appendix and Index', Parliamentary Papers, British House of Commons (1837) no. 425.

'The Revd. Duncan McNab and the Aborigines', Queensland Votes and Proceedings (1876), p. 172. 


\section{Secondary sources}

Attwood, Bain 2009, Possession: Batman's Treaty and the Matter of History, Miegunyah Press, Melbourne.

Attwood, Bain and Andrew Markus 2009, The Struggle for Aboriginal Rights: A Documentary History, Allen \& Unwin, Sydney.

Ballantyne, Tony 2002, Orientalism and Race: Aryanism in the British Empire, Palgrave, Basingstoke.

Ballantyne, Tony and Antoinette Burton 2005, 'Introduction: bodies, empires, and world histories', in Bodies in Contact: Rethinking Colonial Encounters in World History, Tony Ballantyne and Antoinette Burton (eds), Duke University Press, Durham: 1-18.

- (eds) 2009, Moving Subjects: Gender, Mobility and Intimacy in an Age of Global Empire, University of Illinois Press, Urbana and Chicago.

Banivanua Mar, Tracey 2007, Violence and Colonial Dialogue: The Australian-Pacific Indentured Labor Trade, University of Hawai'i Press, Honolulu.

Banner, Stuart 2007, Possessing the Pacific: Land, Settlers, and Indigenous People from Australia to Alaska, Harvard University Press, Cambridge.

Barker, John 2005, 'Where the missionary frontier ran ahead of empire', in Missions and Empires, Oxford University Press, Oxford: 86-106.

Barwick, Diane 1998, Rebellion at Coranderrk, Aboriginal History Monograph Series 5, Aboriginal History Inc, Canberra.

Barwick, RE and Diane Barwick 1984, 'A Memorial for Thomas Bungaleen, 18471865', Aboriginal History 8(1): 9-11.

Belich, James 1996, Making Peoples: A History of the New Zealanders from Polynesian Settlement to the End of the Nineteenth Century, Vol 1, Ringwood, Australia.

Blake, Thom 1998, 'Deported....at the sweet will of the government: the removal of Aborigines to reserves in Queensland, 1897-1939', Aboriginal History 22: 51-61.

Boehmer, Elleke 2002, Empire, the National and the Postcolonial, 1890-1920: Resistance in Interaction, Oxford University Press, Oxford.

Broome, Richard 2005, Aboriginal Victorians: A History Since 1800, Allen \& Unwin, Sydney.

- 2010, Aboriginal Australians: A History Since 1788, Allen \& Unwin, Melbourne. 
Byrt, Pauline (transcriber) 2004, The Thomas Papers in the Mitchell Library A Comprehensive Index, Centre for Indigenous Studies, Monash University, Melbourne.

Chappell, David 1971, Double Ghosts: Oceanian Voyagers on Euroamerican Ships, ME Sharpe, New York.

Charters, Clare and Andrew Erueti 2008, Maori Property Rights and the Foreshore and Seabed: The Last Frontier, Victoria University Press, Wellington.

Clark, Ian 1995, Scars on the Landscape: A Register of Massacre Sites in Western Victoria, 1803-1859, Aboriginal Studies Press, Canberra.

Clark, R 1979, 'In search of Beach-la-mar: towards a history of Pacific Pidgin English', Te Reo 22: 3-64.

Coates, D, John Beecham and William Ellis 1837, Christianity the Means of Civilisation: Shown in the Evidence Given Before a Committee of the House of Commons on Aborigines, RB Seeley and W Burnside, London.

Curthoys, Ann and Jessie Mitchell 2012, “"Bring this Paper to the Good Governor": Aboriginal petitioning in Britain's Australian colonies', in Native Claims: Indigenous Law Against Empire, 1500-1920, Saliha Belmessous (ed), Oxford University Press, Oxford: 182-204.

De Costa, Ravindra 2006, A Higher Authority: Indigenous Transnationalism and Australia, UNSW Press, Sydney.

Denoon, Donald 1997, 'Pacific Edens? Myths and realities of primitive affluence', in The Cambridge History of the Pacific Islanders, Donald Denoon and Malama Meleisea with Stewart Firth, Jocelyn Linnekin and Karen Nero (eds), Cambridge University Press, Cambridge: 80-118.

Denoon, Donald, Philippa Mein-Smith and Marivic Wyndham 2000, A History of Australia, New Zealand and the Pacific, Blackwell, Oxford.

Edmonds, Penelope 2010, Urbanizing Frontiers: Indigenous Peoples and Settlers in 19th-Century Pacific Rim Cities, University of British Columbia Press, Vancouver.

Elbourne, Ellecke 2001, Blood Ground: Colonialism, Missions and the Contest for Christianity in the Cape Colony and Britain, 1799-1853, McGill Queens University Press, Montreal.

Etherington, Norman 2005, 'Education and medicine', in Missions and Empires, Norman Etherington (ed), Oxford University Press, Oxford: 261-284. 
IMPERIAL LITERACY AND INDIGENOUS RIGHTS

Facsimiles of the Declaration of Independence and the Treaty of Waitangi, Government Printer, Wellington, 1877.

Fels, Marie 2011, 'I Succeeded Once': The Aboriginal Protectorate on the Mornington Peninsula, 1839-1840, ANU E Press, Canberra.

Goodall, Heather 1990, “"Land in our own country”: The Aboriginal land rights movement in south-eastern Australia, 1860-1914', Aboriginal History 14(1): $1-24$.

Goodall, Norman 1954, A History of the London Missionary Society, Oxford University Press, London.

Gray, Richard 1990, Black Christians and White Missionaries, Yale University Press, New Haven.

Griffiths, Gareth 2005, 'Trained to tell the truth: missionaries, converts, and narration', in Missions and Empires, Norman Etherington (ed), Oxford University Press, Oxford: 153-172.

Gunson, Neil 1978, Messengers of Grace: Evangelical Missionaries in the South Seas, 1797-1860, Oxford University Press, Melbourne.

Hau'ofa, Epeli 2008, 'Our sea of islands', in We Are the Ocean: Selected Works, Epeli Hau' ofa (ed), University of Hawai'i Press, Honolulu: 27-40.

Heartfield, James 2011, The Aborigines Protection Society: Humanitarian Imperialism in Australia, New Zealand, Fiji, Canada, South Africa and the Congo, 1836-1909, Hurst and Company, London.

Holm, John 1992, 'Atlantic meets Pacific: lexicon common to the English-based pidgins and creoles', Language Sciences 14(3): 185-196.

Howe, KR 1984, Where the Waves Fall: A New South Sea Islands History from First Settlement to Colonial Rule, Allen \& Unwin, Sydney.

Kawharu, IH (ed) 1989, Waitangi: Maori and Pakeha Perspectives of the Treaty of Waitangi, Oxford University Press, Auckland.

Kenny, Robert 2008, 'Tricks or treats? A case for Kulin knowing in Batman's Treaty', History Australia 5(3): 38.1-38.14.

Laidlaw, Zoe 2004, “" Aunt Anna's Report”: the Buxton women and the Aborigines Select Committee, 1835-37', The Journal of Imperial and Commonwealth History 32(2): 1-28.

Landau, Paul 2005, 'Language', in Missions and Empires, Norman Etherington (ed), Oxford University Press, Oxford: 194-215. 
Lang, Raeburn 2000, 'Indigenous agents of religious change in New Zealand, 1830-1860', Journal of Religious History 24: 279-295.

Lester, Alan 2005, 'Humanitarians and white settlers in the nineteenth century', in Missions and Empires: Oxford History of the British Empire Companion Series, Norman Etherington (ed), Oxford University Press, Oxford: 65-85.

- 2006, 'Imperial circuits and networks: geographies of the British Empire', History Compass 4(1): 124-141.

Lester, Alan and Fae Dussart 2008, 'Trajectories of protection: protectorates of Aborigines in early nineteenth century Australia and Aotearoa New Zealand', New Zealand Geographer 64(3): 205-220.

Lydon, Jane and Jane Carey (eds) (forthcoming), Indigenous Networks: Mobility, Connections and Exchange, Routledge.

McArthur, Norma 1978, 'And, behold, the plague was begun among the people', in The Changing Pacific, Neil Gunson (ed), Oxford University Press, Oxford: 273-282.

McHugh, Paul 1991, The Māori Magna Carta: New Zealand Law and the Treaty of Waitangi, Oxford University Press, Oxford.

Matsuda, Matt 2006, 'AHR Forum: The Pacific', American Historical Review 111(3): 758-780.

- 2012, Pacific Wolds: A History of Seas, Peoples and Cultures, Cambridge University Press, Cambridge.

Maynard, John 2006, " "In the interests of our people": the influence of Garveyism on the rise of Australian Aboriginal political activism', Aboriginal History 29: 1-22.

Mitchell, Jessie 2011, In Good Faith: Governing Indigenous Australia Through God, Charity and Empire, 1825-1855, ANU E Press; Canberra.

Moon, Paul 2002, Te Ara Ki Te Tiriti: The Path to the Treaty of Waitangi, David Ling, Auckland.

O'Brien, Patty 2006, “"Think of me as a woman”: Queen Pomare of Tahiti and Anglo-French imperial contest in the 1840s Pacific', Gender and History 181: 108-129.

Orange, Claudia 2011, The Treaty of Waitangi, 2nd ed, Bridget Williams Books, Wellington, NZ.

Paisley, Fiona 2012, The Lone Protestor, Aboriginal Studies Press, Canberra. 
Plomley, B and KA Henley 1990, The Sealers of Bass Strait and the Cape Barren Island Community, Blubber Head Press, Hobart.

Pybus, Cassandra 2006, Epic Journeys of Freedom: Runaway Slaves of the American Revolution and Their Global Quest for Liberty, Beacon Press, Boston.

Richter, Daniel 2001, Facing East from Indian Country: A Native History of Early America, Harvard University Press, Cambridge and London.

Russell Lynette 2012, Roving Mariners: Australian Aboriginal Whalers and Sealers in the Southern Oceans, 1790-1870, State University of New York, Albany, NY.

Ryan, Lyndall 2012, The Aboriginal Tasmanians: A History since 1803, Allen \& Unwin, Sydney.

Thomas, Nicholas 2012, Islanders: The Pacific in the Age of Empire, Yale University Press, New Haven, CT.

Tryon, Darrell and Jean-Michel Charpentier (eds) 2004, Pacific Pidgins and Creoles: Origins, Growth Development, Mouton de Gruyter, Berlin.

Samson, Jane 2010, 'Translation teams: missionaries, islanders and the reduction of language in the Pacific', in Missionaries, Indigenous Peoples and Cultural Exchange, Patricia Grimshaw and Andy May (eds), Sussex Academic Press, Eastbourne, Portland.

Sanderson, Kay 1983, 'Maori Christianity on the East Coast', New Zealand Journal of History 17: 166-184.

Simon, Judith 1998, 'Anthropology, "native schooling" and Maori: the politics of “cultural adaptation" policies', Oceania 69(1): 61-78.

Standfield, Rachel 2011, “"The vacillating manners and sentiments of these people": mobility, civilisation and dispossession in the work of William Thomas with the Port Phillip Aboriginal Protectorate', Law, Text, Culture 15: 162-185.

- 2012, 'Protection, settler politics and Indigenous politics in the work of William Thomas', Journal of Colonialism \& Colonial History 13(1): n.a.

Thomas, Nicholas 2012, Islanders: The Pacific in the Age of Empire, Yale University Press, New Haven, CT.

Van Toorn, Penny 2006, Writing Never Arrives Naked: Early Aboriginal Cultures of Writing in Australia, Aboriginal Studies Press, Canberra. 
Walter, Maggie and Louise Daniels 2008, 'Personalising the history wars: Woretemoeteryenner's story', International Journal of Critical Indigenous Studies 1(1): 35-44.

Ward, Alan 1974, A Show of Justice: Racial "Amalgamation" in Nineteenth Century New Zealand, Australian National University Press, Canberra.

Weaver, John C 2003, The Great Land Rush and the Making of the Modern World, 1650-1900, McGill-Queen's University Press, Quebec.

Wilkes, Charles 1845, Narrative of the United States Exploring Expedition during the years 1838, 1839, 1840, 1841, 1842, Vol 2, Wiley and Putnam, London.

Williams, David 1999, Te Kooti Tango Whenua: The Native Land Court, 1864-1909, Huia Publishers, Wellington. 